DOI https://doi.org/10.15589/znp2019.2(476).8

УДК 659.152:658

\title{
METHODICAL APPROACHES TO THE RESULTS OF ANALYSIS OF THE EXHIBITION ACTIVITIES OF THE ENTERPRISE THROUGH THE PRISM OF INNOVATIVE DEVELOPMENT
}

\section{МЕТОДИЧНІ ПІДХОДИ ДО АНАЛІЗУ РЕЗУЛЬТАТИВНОСТІ ВИСТАВКОВОЇ ДІЯЛЬНОСТІ ПІДПРИЕМСТВА-ЕКСПОНЕНТА КРІЗЬ ПРИЗМУ ІННОВАЦІЙНОГО РОЗВИТКУ}

\author{
Alla O. Kasych \\ kasich.alla@gmail.com \\ ORCID: 0000-0001-7019-1541 \\ Nataliia M. Kyrylko \\ Natashaoklirik@bigmir.net \\ ORCID: 0000-0002-9099-5229
}

\author{
А. О. Касич, \\ докт. екон. наук, професор, \\ завідувач кафедри менеджменту \\ Н. М. Кирилко, \\ ст. викладач кафедри менеджменту
}

\section{Kyiv National University Technology and Design, Kyiv \\ Київький національний університет технологій та дизайну, м. Київ}

\begin{abstract}
The purpose of the article is to investigate and improve methodological approaches to the analysis of the exhibition activity of the exhibitor company on the basis of its innovative development. The relevance of this topic lies not only in the systematization of methodological approaches to the exhibition activity of the exhibition company, but also in the analysis of its immediate results.

The methodology of the research is based on the effectiveness of using the tools to determine the stages of analysis of the effectiveness of the exhibiting activity of the exhibiting company in the context of innovative development.

Results. In the course of the research, methodological approaches to the analysis of the results of the exhibitor's participation in exhibitions of innovative direction were systematized.

Scientific novelty is the objective determination of new stages in the methodology of analyzing the results of the exhibitor's activity on the basis of innovative development.

This makes it possible to state the need for consistency in the use of the proposed stages, their objectives and indicators of improved methodology.

Practical meaning. The results of the study are aimed at solving the problem of determining methodological approaches to the analysis of the performance of the exhibition activity of the exhibiting company through the prism of innovative development. Based on the analysis of the proposed methodological approaches, their advantages and disadvantages were identified. It is determined that the main methodological approaches should be considered: systemic, situational, process and complex. The general system of indicators of the analysis of the results of the exhibition activity of the exhibiting company in the context of innovative solutions is considered.

The method of analysis of the results of the exhibition activity of the participating enterprise has been improved. The necessity to apply new steps in the analysis of the results of the exhibiting activity of the exhibiting company with consideration of innovative orientation is substantiated.
\end{abstract}

Key words: enterprises-exhibitors; innovation development; methodical approaches; integrated approach; results from participation; system of indicators; analysis of the effectiveness of exhibition activities.

Анотація. Метою статті $\epsilon$ дослідження та удосконалення методичних підходів до аналізу результативності виставкової діяльності підприємства-експонента на основі його інноваційного розвитку. Актуальність цієї теми полягає не лише у систематизації методичних підходів виставкової діяльності підприємства-експонента, а й у аналізі його безпосередньої результативності.

Методологія дослідження грунтується на ефективності використання інструментарію щодо визначення етапів аналізу результативності виставкової діяльності підприємства-експонента у контексті інноваційного розвитку. Результати. В процесі проведеного дослідження було систематизовано методичні підходи до аналізу результативності участі підприємства-експонента у виставкових заходах інноваційного спрямування.

Наукова новизна полягає у об'єктивному визначенні нових етапів методики аналізу результативності виставкової діяльності підприємства-експонента на основі інноваційного розвитку.

Це дає змогу стверджувати про необхідність дотримання системності під час використання запропонованих етапів, їх завдань та показників удосконаленої методики. 
Практична значимість. Отримані результати дослідження спрямовані на вирішення проблеми щодо визначення методичних підходів до аналізу результативності виставкової діяльності підприємства-експонента через призму інноваційного розвитку. Виходячи з аналізу запропонованих методичних підходів, було виявлено їх переваги та недоліки. Визначено, що основними методичними підходами слід вважати: системний, ситуаційний, процесний та комплексний. Розглянуто загальну систему показників аналізу результативності виставкової діяльності підприємства-експонента в контексті інноваційних рішень.

Удосконалено методику аналізу результативності виставкової діяльності підприємства учасника. Обгрунтовано необхідність застосування нових етапів щодо аналізу результативності виставкової діяльності підприємстваекспонента з урахуванням інноваційної спрямованості.

Ключові слова: підприємство-експонент; інноваційний розвиток; методичні підходи; комплексний підхід; результативність; система показників; аналіз результативності виставкової діяльності.

\section{ПОСТАНОВКА ПРОБЛЕМИ}

В сучасних умовах виставковий бізнес є багаторівневим процесом, який сприяє мобільності товарних ринків та активізації інноваційного розвитку підприємств-експонентів. Для підприємств, які здійснюють виробництво нової інноваційної продукції, участь у виставкових заходах дозволяє отримувати інформацію про конкурентів набагато швидше та зрозуміти ринкову ситуацію.

Оскільки виставкова діяльність є досить важливим напрямом для розвитку підприємств-експонентів, вона потребує системного дослідження, основою якого має бути методика аналізу результативності виставкової діяльності підприємства-експонента, в тому числі в контексті його інноваційного розвитку. В науковій літературі $[1 ; 8 ; 12 ; 23 ; 22 ; 28$; 29; 31] представлено декілька методичних підходів до аналізу результативності виставкової діяльності підприємства-експонента. Однак положення усталеної методики не розроблено. Тому питання удосконалення методичних підходів до аналізу результативності виставкової діяльності підприємства-експонента на основі інноваційного розвитку є досить актуальним.

Метою статті $\epsilon$ систематизація та удосконалення наявних методичних підходів до аналізу результативності виставкової діяльності підприємства-експонента в контексті інноваційного розвитку.

\section{АНАЛІЗ ОСТАННІХ ДОСЛІДЖЕНЬ І ПУБЛІКАЦІЙ}

Дослідження методичних підходів до аналізу результативності виставкової діяльності підприємства представлені в працях вітчизняних та зарубіжних науковців, а саме: Н.В. Александрової, І.К. Філоненка [1], Ф.І. Шаркова [31], І.В. Альошиної [7], А.О. Касич [14], Л.В. Лукашової [17], Г.Т. П'ятницької [23], Л. Е.Стровського [20], У. Роберта Рідела [24], Джона Філлінга і Кімберлі Д. Пелле [11] та ін.

На думку Ф.І. Шаркова [31], результатом оцінки ефективності є основа оптимізації виставкової політики підприємства. Він пояснює це першочерговою необхідністю корегування виставкового бюджету та оптимізації витрат.
Для визначення оцінки ефективності виставкового процесу доцільно паралельно проводити дослідження якісних та кількісних результатів виставкових заходів (В3). Такої думки дотримується також I.В. Альошина [7].

Узагальнений аналіз результативності участі підприємства у виставкових заходах розглядають У. Роберт Рідел, Джон Філлінг і Д. Кімберлі Пелле [11].

Варто зазначити, що в своїх працях Л.В. Лукашова [17], Г.Т. П'ятницька [23] та Л.Е. Стровський [20] застосували методику аналізу підбору та розрахунку виставкового персоналу і оцінку ефективності участі підприємства у В3.

Зокрема, організаційно-адаптивний підхід до аналізу виставкових заходів у період довиставкової та поствиставкової стадій підприємства-експонента застосовує В.Г. Петелін [22].

Питання результативності виставкової діяльності підприємства-експонента з точки зору маркетинговоорієнтованого підходу розглядає В. Пекар [21]. Під час визначення ефективності виставкових заходів, окрім трьох під етапів - вивчення ринку, зв'язків 3 громадкістю та поствиставкової аналітичної роботи, він виокремлює питання підтримання обізнаності про інновації й новітні технології. Такий підхід створює умови до більш розгорнутого вивчення інноваційних розробок та прогресивних технологій підприємстваекспонента, які представляються під час виставкових заходів.

Таким чином, у науковій літературі досить детально, однак фрагментарно, представлені питання методичних підходів до аналізу ефективності виставкової діяльності. При цьому фактично відсутні рекомендації щодо дослідження результативності виставкової діяльності у контексті інноваційного розвитку підприємства-експонента.

\section{ВИКЛАД ОСНОВНОГО МАТЕРІАЛУ ДОСЛІДЖЕННЯ}

В сучасних умовах активізації інноваційних процесів на підприємстві-експоненті розвиток виставкової діяльності набуває актуального значення під час отримання кінцевих результатів від його участі та отримання загальної результативності. Сутність 
поняття «результату» та «результативності» досліджено науковцями М. Месконом, М. Альбертом, Ф. Хедоуррі [19]; П. Друкером [10]; А.Д. Шереметом, Р.С. Сайфуліним [32], Е. Дж. Доланом [9], Л.Г. Критсотакісом [16] та інші. Ці визначення є досить ототожненими.

В енциклопедичному словнику В.Д. Бакуменко пояснює, що поняття «результату» є етапом діяльності, коли визначено наявність переходу якості в кількість і кількості в якість, а результативність є показником, який характеризує дієвість, досягнення, ступінь завершення певної роботи й реалізації визначених цілей, показує, що було зроблено внаслідок здійснення певних зусиль і витрат ресурсів [34, с. 615].

Зокрема, М. Мескон [19] розглядає таке поняття, як результативність, з точки зору зовнішньої ефективності, яка оцінює досягнення цілей підприємства, що відображає не лише економічність, але й характеризує взаємовідносини з зовнішнім середовищем.

Трактує «результативність» як величину, що характеризує ступінь ділової активності підприємства, А.Д. Шеремет [32, с. 176]. 3 цим визначенням можна погодитись, тому що розвиток внутрішнього та зовнішнього середовища підприємства має вплив на результативність його діяльності.

Також у стандарті 180:9000:2001 зазначено, що результативність "effectiveness" - це ступінь реалізації запланованої діяльності та досягнення запланованих результатів [33]. Для глибокого дослідження методичних підходів до аналізу результативності виставкової діяльності доцільно окреслити поняття результат, результативність у сфері виставкової діяльності. Варто погодитись 3 науковцем Л.Г. Критсотакісом [16, с. 224] в тому, що перевірка результатів участі підприємства-експонента у виставкових заходах (В3) передбачає систематичний аналіз всіх економічних та зовнішньоекономічних факторів, які проявилися під час виставкових заходів. Для наступного визначення результативності участі у виставковій діяльності підприємства-експонента науковці С.Б. Гусев, В.А. Прокудін та А.Г. Салащенко [7] зауважують, що є також вартісний критерій, який визначається шляхом відношення участі підприємства-експонента у В3 до вартості укладеного контракту.

Отже, під результативністю виставкової діяльності підприємства-експонента внаслідок здійснення певних зусиль і витрат ресурсів слід розуміти реалізацію поставлених цілей, а саме: знайомство з лідерами виставкового бізнесу; новими ідеями та прогресивними технологіями і устаткуванням; просування інноваційної продукції чи послуг з метою визначення своєї привабливості як потенційного об'єкта інвестування; укладання контрактів та отримання додаткових прибутків.

У сучасних умовах результатом виставкової діяльності в контексті інноваційного розвитку є ознайомлення підприємства-експонента 3 продуктовими та процесними інноваціями конкурентів, вивчення передових технологій та нового модернізованого обладнання. Так, проаналізувавши бачення науковців, об'єктивним результатом виставкової діяльності підприємства-експонента слід вважати:

- отримання інформації про конкурентів та їх новітню продукцію і послуги. Це є поштовхом до створення інноваційної більш конкуруючої продукції або надання більш якісних інноваційних послуг;

- отримання інформації про передові технології та сучасне обладнання. Це дає можливість розширити коло своїх партнерів і зміцнити кількість контактів для співпраці, а також придбати модернізоване обладнання;

- досвід роботи виставкового персоналу (стендистів). Це сприяє професійному підходу підприємства-експонента до участі у виставкових заходах інноваційного спрямування та створенню свого бренда; зміцнення ділової репутації та іміджу підприємства-експонента. Це впливає на загальний розвиток підприємства-експонента та його пізнаваність на виставковому та пост виставковому етапах;

- $\quad$ укладання договорів 3 потенційними споживачами та збільшення кількості контактів. Це зміцнює позиції підприємства-експонента у виставковому бізнесі;

- покращення інвестиційної привабливості. Це дає новий поштовх для виходу підприємства-експонента на міжнародний ринок;

- знаходження партнерів. Це сприяє розширенню географічних можливостей щодо збуту новітньої продукції та залучення прогресивних технологій;

отримання комерційного прибутку та можливість його збільшення. Це здатність до повної самореалізації підприємства-експонента і подовження його життєвого циклу.

У своїй праці Е.М. Біжанова [3, с. 22] дотримується думки, що результативність виставкової діяльності підприємства-експонента передбачає визначення ступеня досягнення поставлених цілей, а саме, коли мета досягнута повністю (на 100\%), або досягнута частково. Для досягнення поставлених цілей та максимальної результативності виставкової діяльності підприємства в контексті інноваційного розвитку доцільним $\epsilon$ вивчення та удосконалення методичних підходів. Методикою аналізу результативності виставкової діяльності займались такі науковці, як Л.Е. Стровский, Е.Д. Фролова [20, с. 24], О.В. Гуменна [6, с. 22], Л.Е. Сюрко [26, с. 343-347] та інші.

Зокрема, О.В. Гуменна [6, с. 5-18] виокремлює питання щодо системи показників та методів оцінки результативності з позиції експонентів, де передбачає застосування значної їх кількості на передвиставковій, виставковій та поствиставковій стадії. На кожній стадії використовуються такі методи: маркетингових досліджень, експертних оцінок, економіко-статистичних і соціологічних та методів оцінки ефективності. 
Слід зауважити, що на результат виставкової діяльності впливають показники підприємства-експонента та рівень кваліфікації персоналу, ступінь його підготовки до участі у виставкових заходах (В3), так відмічає у своїй праці Л.Е. Сюрко [26, с. 343-347]. Він вважає, що аналіз результативності виставкових заходів залежить від системності методики збору інформації, методики її обробки та застосування окремо для експонентів та організаторів.

Дослідженням методики аналізу результативності виставкової діяльності в контексті інноваційного розвитку займались Г.Т. П’ятницька [23, с. 26-33], Балінт Кадар [13, с. 23-31], Б.В. Гагарін та Ю.Д. Ільїн [5, c. 116-120] та інші.

У цих працях розроблено кластерний і науковопрактичний підходи до оцінки ефективності інноваційної направленості, але відсутні етапи, які відображали б роль виставкової діяльності в контексті інноваційного розвитку.

Певний фрагментарний підхід представлено в працях Н.В. Александрової і І.К. Філоненко [1], А.А. Фарберова [28, с. 4-19], але загалом методика відсутня. В процесі дослідження та систематизації праць вчених виокремлено методичні підходи, які представлено на табл. 1 .

Отже, зазначені вище методичні підходи до аналізу результативності щодо участі підприємства-експонента у виставкових заходах дозволяють досить фрагментарно визначати показники результативності виставкової діяльності підприємства-експонента на основі його інноваційного розвитку.

Методика аналізу результативності інноваційної діяльності розглядає: встановлення поточного стану інноваційної діяльності підприємства-експонента; виявлення впливу впровадження нововведень та інновацій і сприйняття їх ринком; визначення ступеня ефективності супутніх до виробництва процесів, орієнтованих на ринок збуту, встановлення типу інноваційної поведінки і можливості до збільшення ринкової частки; нарощення конкурентоспроможності на зовнішніх ринках.

Дослідження методичних підходів до аналізу результативності виставкової діяльності підприємства-експонента дозволяє констатувати те, що використання саме комплексного методичного підходу $є$ найбільш актуальним та вагомим (рис. 1).

На основі перерахованих підходів вчені $[1 ; 5 ; 7$; $12 ; 13 ; 16-18 ; 20-23 ; 27-31]$ у своїх працях виокремлюють такі етапи аналізу виставкової діяльності:

1) дослідження ринку виставкових послуг;

2) аналіз підприємства-експонента на участь у виставкових заходах;

3) аналіз ризикованості участі підприємстваекспонента у виставкових заходах;

4) інтенсивність участі підприємства-учасника у виставкових заходах;

5) аналіз результативності виставкової діяльності підприємства-експонента у контексті інноваційного розвитку.

Однак виставкова діяльність набуває все більшого значення в контексті активізації інноваційних процесів, а тому наявні методичні положення слід розглядати та доповнити інноваційним складником.

Саме тому нами пропонується удосконалення методики аналізу результативності виставкової діяльності підприємства-експонента в контексті активізації інноваційних процесів (табл. 2).

Показники, що характеризують виставкову діяльність підприємства-експонента в контексті інноваційної діяльності, повинні використовуватись під час розробки довгострокових та короткострокових планів ідоповнюватинаявну системузвітності, тобтотакасистема показників повинна стати діючим інструментом

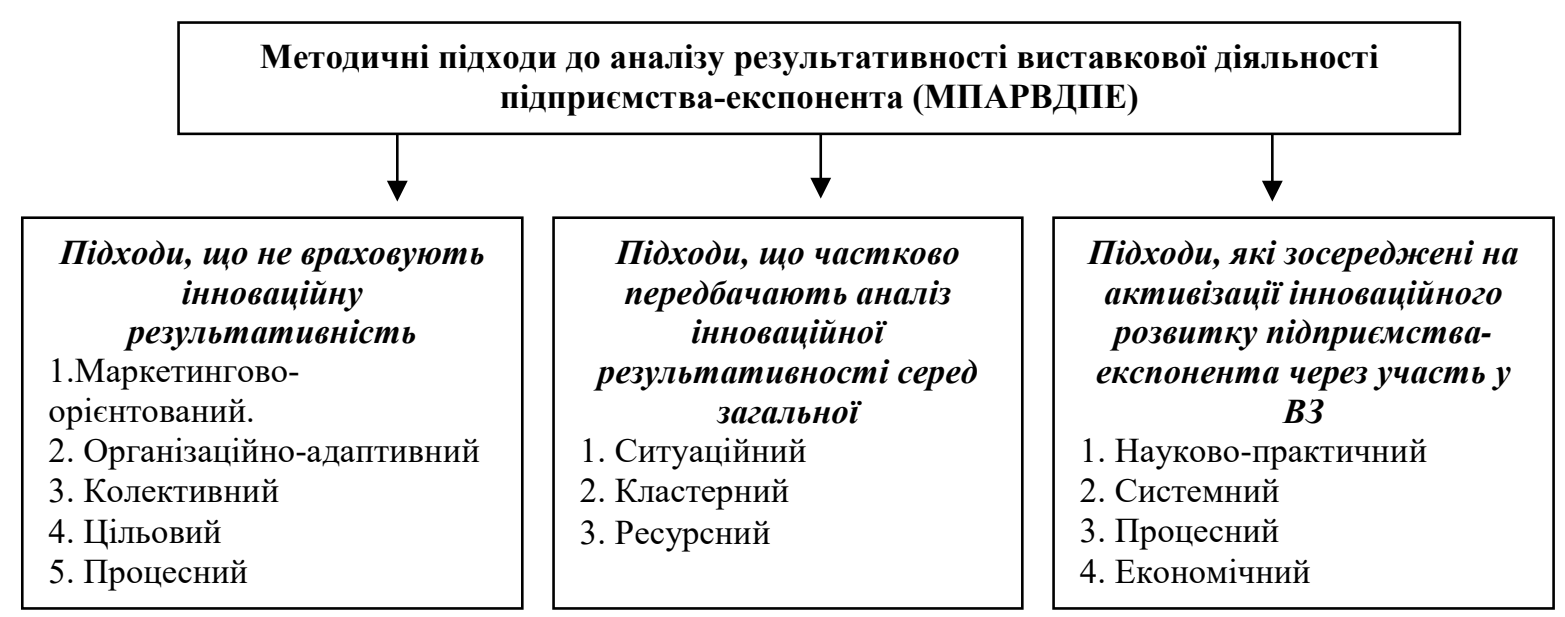

Рис. 1. Групування методичних підходів до аналізу результативності виставкової діяльності в контексті інноваційного розвитку підприємства-експонента

Джерело: складено авторами 
Таблиця 1. Загальна характеристика методичних підходів до аналізу результативності щодо участі підприємства-експонента у виставкових заходах у процесі інноваційного розвитку

\begin{tabular}{|c|c|c|}
\hline Назва методичного підходу & Переваги методичного підходу & Недоліки методичного підходу \\
\hline $\begin{array}{l}\text { Маркетингово-орієнтований зо- } \\
\text { середжений на вивчення ринку та } \\
\text { знаходження нового потенційного } \\
\text { споживача з метою максимально } \\
\text { відповідного задоволення його по- } \\
\text { требам, смакам і бажанням. }\end{array}$ & $\begin{array}{l}\text { - дає змогу підтримувати обізнаність про } \\
\text { інновації й новітні технології завдяки } \\
\text { своєчасній та якісній поінформованості; ство- } \\
\text { рення умов до більш розгорнутого вивчення } \\
\text { інноваційних розробок та прогресивних } \\
\text { технологій підприємства-експонента, які пред- } \\
\text { ставляються під час виставкових заходів }\end{array}$ & $\begin{array}{l}\text { - користувач інформації не за- } \\
\text { вжди використовує надану ін- } \\
\text { формацію, а у разі використання } \\
\text { немає гарантії, що на ії основі } \\
\text { буде прийняте правильне управ- } \\
\text { лінське рішення щодо виставкової } \\
\text { діяльності }\end{array}$ \\
\hline $\begin{array}{l}\text { Організаційно-адаптивний } \\
\text { включає організацію та поетапне } \\
\text { виконання поставлених цілей і } \\
\text { завдань виставкової діяльності } \\
\text { підприємства-експонента на } \\
\text { довиставковій стадії }\end{array}$ & $\begin{array}{l}\text { - дає змогу пристосовуватись підприємствам } \\
\text { учасникам виставкових заходів до змін; } \\
\text { - забезпечує } \\
\text { стабільність і управління виставковою } \\
\text { діяльністю } \\
\text { підприємства-експонента }\end{array}$ & $\begin{array}{l}\text { - недотримання } \\
\text { часових характеристик на будь- } \\
\text { якій стадії участі підприємства- } \\
\text { експонента; }\end{array}$ \\
\hline $\begin{array}{l}\text { Кластерний направлений на } \\
\text { реалізацію спільних інтересів } \\
\text { підприємств-експонентів, що кон- } \\
\text { курують між собою і діяльність } \\
\text { яких спрямована на впровадження } \\
\text { інноваційних змін }\end{array}$ & $\begin{array}{l}\text { - дозволяє: підвищувати туристичну привабли- } \\
\text { вість регіону (країни), формувати та зміцню- } \\
\text { вати позитивний імідж та надійну ділову репу- } \\
\text { тацію регіону в очах галузевих співтовариств; } \\
\text { розширювати можливості експонентів в захо- } \\
\text { дах форматів “В-tо-В” та “В-tо-С” у активізації } \\
\text { просування та збільшення обсягів продажу } \\
\text { продукції кінцевим споживачам; якісно при- } \\
\text { множувати ділові контакти у тому числі з по- } \\
\text { тенційними українськими та іноземними інвес- } \\
\text { торами; прискорювати трансфер інноваційних } \\
\text { технологій; скорочувати часовий термін обміну } \\
\text { інформацією та думками щодо досягнень НТП. }\end{array}$ & $\begin{array}{l}\text { - наявність ризиків так званого } \\
\text { «гальмування» об’єднання через } \\
\text { відсутність у потенційних учасни- } \\
\text { ків чіткого розуміння доцільності } \\
\text { та виправданості спільного розви- } \\
\text { тку та погану поінформованість; } \\
\text { - можливе «очікування на швид- } \\
\text { кий та відразу вагомий резуль- } \\
\text { тат»; } \\
\text { - відсутність або нестача кваліфі- } \\
\text { кованих кадрів для забезпечення } \\
\text { ефективності виставкової діяль- } \\
\text { ності; } \\
\text { - низька виставкова культура та } \\
\text { грамотність. }\end{array}$ \\
\hline $\begin{array}{l}\text { Pесурсний } \\
\text { передбачає визначення і оцінку пе- } \\
\text { реліку сукупності матеріальних і } \\
\text { нематеріальних чинників і засобів, } \\
\text { що забезпечують функціонування } \\
\text { виставкової діяльності } \\
\text { підприємства-експонента }\end{array}$ & $\begin{array}{l}\text { - дозволяє оцінити рівень розвитку виставкової } \\
\text { діяльності підприємства-експонента на підста- } \\
\text { ві визначення її ресурсного потенціалу (кадро- } \\
\text { вих, матеріальних та інформаційних ресурсів), } \\
\text { що забезпечують цей вид діяльності }\end{array}$ & $\begin{array}{l}\text { - чітке визначення переліку якіс- } \\
\text { них показників; } \\
\text { - отримання повної та достовір- } \\
\text { ної інформації про загальний стан } \\
\text { виставкової діяльності }\end{array}$ \\
\hline $\begin{array}{l}\text { Сuтуачійний передбачає розгляд } \\
\text { та управління конкретними ситу- } \\
\text { аціями в процесі участі підпри- } \\
\text { ємства-експонента у виставкових } \\
\text { заходах та прийняття відповідних } \\
\text { рішень. }\end{array}$ & $\begin{array}{l}\text { - дає змогу } \\
\text { підприємствам-експонентам бути ризикостій- } \\
\text { кими в умовах розвитку інноваційних процесів } \\
\text { та під час виставкової діяльності }\end{array}$ & $\begin{array}{l}\text { - складність досягнення стабіль- } \\
\text { ності на всіх етапах життєвого } \\
\text { циклу підприємства-експонента }\end{array}$ \\
\hline $\begin{array}{l}\text { Колективний визначає } \\
\text { відкритість та відповідальність } \\
\text { управління виставковою } \\
\text { діяльністю підприємства- } \\
\text { експонента }\end{array}$ & $\begin{array}{l}\text { - дозволяє ставити спільні цілі та завдання під } \\
\text { час втілення командної роботи підприємства } \\
\text { для участі у виставкових заходах, балансува- } \\
\text { ти відповідальність за бачення та результати } \\
\text { участі. }\end{array}$ & $\begin{array}{l}\text { - послаблення кураторського ав- } \\
\text { торитету }\end{array}$ \\
\hline $\begin{array}{l}\text { Системний розглядається як су- } \\
\text { купність властивостей цілісності, } \\
\text { взаємозалежності та взаємодії еле- } \\
\text { ментів виставкової діяльності під- } \\
\text { приємства-експонента, що мають } \\
\text { вихід, вхід, зв’язок із зовнішнім } \\
\text { середовищем та зворотній зв’язок }\end{array}$ & $\begin{array}{l}\text { - дає змогу: } \\
\text { впливати підприємствам-експонентам на при- } \\
\text { родне, соціальне, політичне, інформаційно- } \\
\text { культурне й етичне середовище та отримувати } \\
\text { матеріальний і нематеріальний ефект від участі } \\
\text { у виставкових заходах; впроваджувати та поши- } \\
\text { рювати нові технології винаходів, нових ідей; } \\
\text { - створює умови до більш розгорнутого ви- } \\
\text { вчення інноваційних розробок та прогресивних } \\
\text { технологій підприємства-експонента, які пред- } \\
\text { ставляються під час виставкових заходів }\end{array}$ & $\begin{array}{l}\text { - не визначає основні змінні, що } \\
\text { впливають на функцію управлін- } \\
\text { ня, } \\
\text { - невідомий вплив навколиш- } \\
\text { нього середовища на результати } \\
\text { діяльності підприємства-експо- } \\
\text { нента }\end{array}$ \\
\hline
\end{tabular}




\begin{tabular}{|c|c|c|}
\hline $\begin{array}{l}\text { Науково-практичний } \\
\text { зосереджує увагу на можливості } \\
\text { фокусувати забезпечення іннова- } \\
\text { ційного розвитку на всіх стадіях } \\
\text { виставкової діяльності підпри- } \\
\text { ємств-експонентів, які є лідерами } \\
\text { ринку }\end{array}$ & $\begin{array}{l}\text { - дозволяє створювати структурні й архітек- } \\
\text { турні інновації - інтерактивні приміщення } \\
\text { (експозиційні зали, павільйони і центри ділової } \\
\text { активності), які будуть слугувати лабораторія- } \\
\text { ми для представлення нововведень з виробни- } \\
\text { цтва, прогресивних технологій підприємств- } \\
\text { учасників та їх перспективного партнерства } 3 \\
\text { лідерами ринку та інвесторами }\end{array}$ & $\begin{array}{l}\text { - розраховано тільки на коло під- } \\
\text { приємств-учасників, які прагнуть } \\
\text { до постійного впровадження та } \\
\text { реалізацію інноваційних рішень в } \\
\text { розробках та технологіях }\end{array}$ \\
\hline $\begin{array}{l}\text { Цільовий } \\
\text { передбачає ступінь досягнен- } \\
\text { ня цілей участі у виставковій } \\
\text { діяльності підприємства- } \\
\text { експонента }\end{array}$ & $\begin{array}{l}\text { - сфокусованість на координацію всього спек- } \\
\text { тру цілей для отримання } \\
\text { максимального прибутку } \\
\text { підприємством-експонентом; } \\
\text { - дає змогу визначити оцінку ефективності } \\
\text { виставкової діяльності підприємства- } \\
\text { експонента }\end{array}$ & $\begin{array}{l}\text { - недосконалість планування бю- } \\
\text { джету щодо участі підприємства- } \\
\text { експонента у В3 }\end{array}$ \\
\hline
\end{tabular}

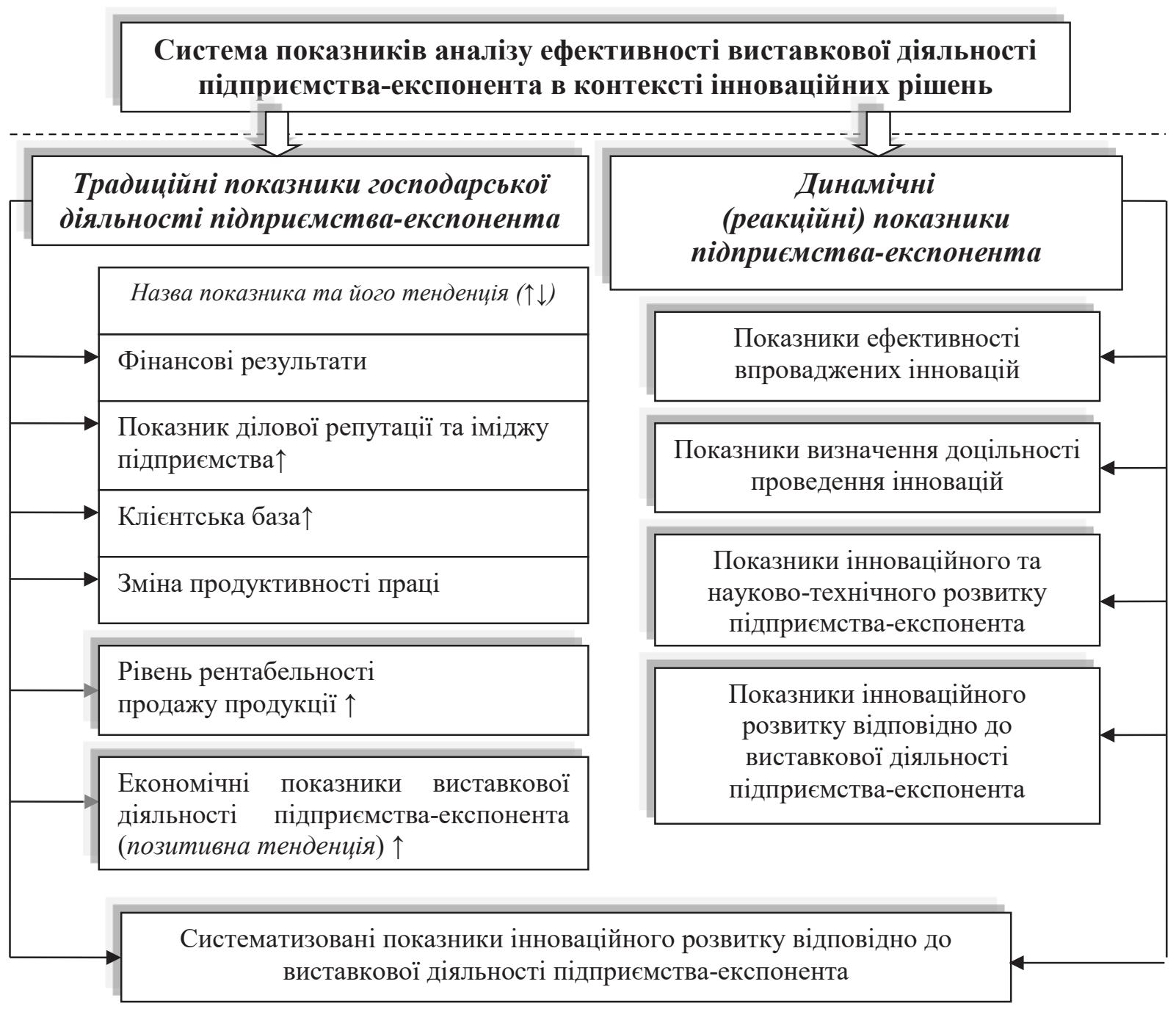

Рис. 2. Методика аналізу виставкової діяльності підприємства-експонента в контексті інноваційного розвитку Джерело: розроблено авторами 
Таблиця 2. Удосконалена методика аналізу результативності виставкової діяльності підприємства-експонента в контексті інноваційного розвитку

\begin{tabular}{|c|c|c|}
\hline Назва етапу & Завдання & Показники \\
\hline $\begin{array}{l}\text { 1. Оцінка інноваційної } \\
\text { орієнтації виставкової ді- } \\
\text { яльності підприємства-екс- } \\
\text { понента }\end{array}$ & $\begin{array}{l}\text { Виявлення типових процедур } \\
\text { виставкової діяльності, які } \\
\text { передбачають інноваційну орі- } \\
\text { єнтацію }\end{array}$ & $\begin{array}{l}\text { - частка у виставках продуктових інновацій; } \\
\text { - частка у виставках технологічних інновацій; } \\
\text { - кількість персоналу підприємства-експонента, } \\
\text { задіяного у виставкових заходах інноваційного спряму- } \\
\text { вання: } \\
\text { - частка інноваційної продукції у загальному обсязі } \\
\text { виробів до і після участі підприємства-експонента у ви- } \\
\text { ставкових заходах інноваційного спрямування, од. }\end{array}$ \\
\hline $\begin{array}{l}\text { 2. Оцінка інноваційної } \\
\text { спрямованості виставкової } \\
\text { діяльності } \\
\text { підприємств-конкурентів }\end{array}$ & $\begin{array}{l}\text { Формування ресурсу підпри- } \\
\text { ємств-конкурентів та підсумків } \\
\text { їх виставкової діяльності }\end{array}$ & $\begin{array}{l}\text { - кількість підприємств-конкурентів, що були } \\
\text { представлені на виставці інноваційного спрямування } \\
\text { (інтенсивність конкуренції); } \\
\text { - характер розподілу ринкових часток між конкурента- } \\
\text { ми; } \\
\text { - позиція (ранг) підприємства-експонента у виставково- } \\
\text { му бізнесі; } \\
\text { - якість використання комунікативних та інформаційних } \\
\text { процесів підприємства-експонента }\end{array}$ \\
\hline $\begin{array}{l}\text { 3. Аналіз структури та ди- } \\
\text { наміки витрат на інновацій- } \\
\text { ну діяльність } \\
\text { підприємства-експонента }\end{array}$ & $\begin{array}{l}\text { - Отримання еталонних } \\
\text { показників з якісними та } \\
\text { кількісними характеристиками; } \\
\text { - Своєчасне врахування всіх } \\
\text { необхідних витрат щодо участі } \\
\text { підприємства-експонента у } \\
\text { виставках інноваційного спря- } \\
\text { мування. }\end{array}$ & $\begin{array}{l}\text { - витрати на рекламні заходи щодо інноваційної } \\
\text { продукції на підготовчому етапі участі підприємства- } \\
\text { експонента у виставкових заходах інноваційного спряму- } \\
\text { вання, грн.; } \\
\text { - витрати на підвищення кваліфікації персоналу } \\
\text { підприємства-експонента щодо участі у виставкових за- } \\
\text { ходах інноваційного спрямування, грн.; } \\
\text { - витрати на модернізацію обладнання підприємства- } \\
\text { експонента, грн.; } \\
\text { - собівартість інноваційних видів продукції } \\
\text { підприємства-експонента, грн. }\end{array}$ \\
\hline $\begin{array}{l}\text { 4. Аналіз результативності } \\
\text { участі у виставкових захо- } \\
\text { дах підприємства-експонен- } \\
\text { та в контексті інноваційно- } \\
\text { го розвитку }\end{array}$ & $\begin{array}{l}\text { - Встановлення кількості } \\
\text { потенційних споживачів } \\
\text { інноваційної продукції з по- } \\
\text { дальшою метою укладення } \\
\text { угод на їі збут; } \\
\text { - Дослідження кількості } \\
\text { організацій і підприємств, } \\
\text { зацікавлених у співробітництві } \\
\text { з метою інвестування сумісних } \\
\text { розробок щодо випуску } \\
\text { інноваційної продукції; } \\
\text { - Визначення комерційного } \\
\text { та некомерційного результатів } \\
\text { участі підприємства- } \\
\text { експонента у виставках } \\
\text { інноваційного спрямування }\end{array}$ & $\begin{array}{l}\text { - кількість отриманих інноваційних ідей підприємства- } \\
\text { експонента під час участі у виставкових заходах } \\
\text { інноваційного спрямування, од.; } \\
\text { - участь і уявлення підприємства-експонента на } \\
\text { конференціях, симпозіумах в рамках виставки } \\
\text { інноваційного спрямування; } \\
\text { - обсяг продаж інноваційної продукції, од.; } \\
\text { - кількість налагоджених контактів з потенційними спо- } \\
\text { живачами, що зацікавлені інноваційною продукцією / } \\
\text { послугами; } \\
\text { - кількість укладених договорів на інноваційну } \\
\text { продукцію / послуги; } \\
\text { - кількість партнерів, знайдених підприємствами- } \\
\text { експонентами під час участі у виставкових заходах } \\
\text { інноваційного спрямування, од.; } \\
\text { - кількість відгуків експертів щодо презентації } \\
\text { інноваційної продукції підприємства-експонента; } \\
\text { - контент-аналіз ЗмІ (резонанс у пресі); } \\
\text { - частка ділової репутації та іміджу підприємства- } \\
\text { експонента; } \\
\text { - фінансовий результат від участі підприємства- } \\
\text { експонента у виставкових заходах інноваційного } \\
\text { спрямування: (дохід від реалізації інноваційної } \\
\text { продукції підприємства-експонента; прибуток від } \\
\text { участі підприємства-експонента у виставкових заходах } \\
\text { інноваційного спрямування), грн.; } \\
\text { - виправданість інновацій підприємства-експонента, \%. }\end{array}$ \\
\hline
\end{tabular}




\section{ЕКОНОМІКА ТА МЕНЕДЖМЕНТ №2-2019}

управління виставковою діяльністю підприємстваекспонента, а саме давати комплексне уявлення про загальний стан підприємства (рис. 2).

Зокрема, можна констатувати те, що у виставковій діяльності підприємства-експонента центральне місце посідає його процес інноваційного розвитку, від можливостей використання, впровадження і удосконалення якого залежить як ефективність впровадження і реалізація інновацій, так і результативність виставкової діяльності підприємства-експонента загалом.

Висновки. Таким чином, для обгрунтування методичних підходів до аналізу результативності ВД підприємства-експонента в контексті інноваційного розвитку необхідно використовувати:

- nо-перше, комбіновану групу методичних підходів, яка може застосовуватись на мікро- рівні, зокрема в процесі інноваційного розвитку та управління виставковою діяльністю підприємства-експонента. Це дасть можливість вибудувати організацію аналітичних процедур щодо аналізу результативності ВД на підприємстві-експоненті з урахуванням вимог сучасної науки і практики та забезпечити синхронізацію та інтеграцію інноваційних процесів на мікрорівні у відповідності до тенденцій розвитку зовнішніх факторів підприємства-експонента;

- $\quad$ по-друге, методику оцінки ВД підприємстваекспонента за допомогою науково обгрунтованого інтегрального показника інноваційного розвитку, що дозволить систематизувати показники базуючись на необхідності врахування взаємозв'язків і взаємозалежностей ВД та інноваційних процесів.

\section{REFERENCES}

[1] Aleksandrova, N. V., Fylonenko, Y. К. (2006). Vystavochnyi menedzhment: stratehyia upravlenyia y marketynhovыe kommunykatsyy [Exhibition management: management strategy and marketing communications], $384 \mathrm{P}$.

[2] Artz, R. (2007). Wettbewerbsfähigkeit europäischer Messeveranstalter: Entwicklung und empirische Anwendung eines multidimensionalen Bezugsrahmens [Competitiveness of European trade fair organizers: development and empirical application of a multidimensional frame of reference]. Kulner Wissenschaftsvlg, $408 \mathrm{P}$.

[3] Byzhanova, E. M. (2006). Metody povyshenyia effektyvnosty vystavochnoi deiatelnosty predpryiatyia [Methods of increasing the efficiency of the exhibition activity of the enterprise]. PHU, $22 \mathrm{P}$.

[4] Vdovichena, O. H. (2012). Vystavkovo-yarmarkova diialnist yak faktor sotsialno-ekonomichnoho zrostannia rehionu [Exhibition and fair activities as a factor of socio-economic growth of the region]. DVNZ Uzhhorod. nats. un-t., $236 \mathrm{P}$.

[5] Haharyn, B.V., Ylyn Yu.D. (2008). Metodycheskyi pokhod k otsenke effektyvnosty vystavky ynnovatsyonnoi napravlennosty [Methodical approach to the evaluation of the effectiveness of the exhibition of innovative orientation]. Ynnovatsyy [Innovation], no 3(113), pp. 116-120.

[6] Humenna, O. V. (2005). Vystavkova diialnist v APK [Exhibition activity in AIC] avtoref. dys. Kyiv, NNTs IAE UAAN, $22 \mathrm{P}$.

[7] Gusev E. B., Prokudin, A. G. Salashhenko (2005). Vy`stavochnaya deyatel'nost' v Rossii i za rubezhom [Exhibition activities in Russia and abroad]: uchebno-metod. posobie, $516 \mathrm{P}$.

[8] Dobrobabenko, E. V. (2007). Vыstavka pod «kliuch». Hotovye marketynhovye reshenyia [Turnkey exhibition. Ready marketing solutions], pp.78-88.

[9] Dolan, Э. Dzh., Lyndsei D. ( 1992) Rynok: mykroekonomycheskaia model [Market: microeconomic model]. S.-Pb., 496 P.

[10] Druker, P. F. (1994). Эffektyvnyi upravliaiushchyi [Effective manager]. BCI, 268 P.

[11] John, E. Findling; Kimberly D. Pelle (2015). Encyclopedia of World's Fairs and Expositions [Encyclopedia of Worlds Fairs and Expositions]. McFarland \& Company, $474 \mathrm{P}$.

[12] Jennings, Hannah (2002). Go to the flow: The exhibition design process made visible [Go to the flow: The exhibition design process made visible]. Exhibitionist, 12(1), pp. 34-36.

[13] Kádár, B. (2011). World Exhibitions as laboratories for structural innovation [World Exhibitions as laboratories for structural innovation].Periodica polytechnica, no. 42/1, pp. 23-31.

[14] Kasich, A.O, Nazarova, M.V, Klimovich, T.A. (2008). Innovative products as a basis for increasing the competitiveness of Ukrainian enterprises. [Innovative products as a basis for increasing the competitiveness of Ukrainian enterprises]. Countries and regions: a scientific and production journal. no 2, pp. 66-69.

[15] Kyrylko, N.M. (2015). Upravlinnia pryiniattiam rishennia shchodo uchasti u vystavkovykh zakhodakh pidpryiemstv lehkoi promyslovosti na bazi zastosuvannia metodu "decision tree" [Management of decision making regarding participation in exhibitions of light industry enterprises based on the application of the decision tree method]. Innovatsiina ekonomika [Innovative economy], no 5 (50), pp. 144-152.

[16] Krytsotakys, L. G. (1997). Torgovye vystavki i yarmarki. Tekhnika uchastiya i kommunikaczii. [Trade shows and fairs. Technique of participation and communication]. Os-89, $224 \mathrm{P}$.

[17] Lukashova, L. V. (2009). Organizacziya vistavkovoyi diyal'nosti [Organization of exhibition activities]. KNTEU, 272 P.

[18] Marc, J. Epstein, Adriana, Rejc Buhovac (2006). The Reporting of Organizational Risks for Internal andExternal Decision-Making. [Organizational risks for internal and external decision making]. Society of Management Accountants of Canada (CMA-Canada), 46 P. 
[19] Meskon Maikl, Maikl Albert, Franklyn Khedoury (2019) Osnovy menedzhmenta [Fundamentals of Management]. Vyliams, $672 \mathrm{P}$.

[20] Strovskyi, L. E., Frolova, E. D., Strovskyi, D. L., Osnovy vыstavochno-yarmarochnoi deiatelnosty (2012) [Basics of exhibition and fair activities]. YuNYTY-DANA, $288 \mathrm{P}$.

[21] Pekar, V. O. (2009). Osnovy vystavkovoi diialnosti [Basics of exhibition activity]. Yevroindeks, 166 P.

[22] Petelyn, V. H. (2005). Osnovы menedzhmenta vыstavochnoi deiatelnosty [Basics of exhibition management]. YuNYTYDANA, $400 \mathrm{P}$.

[23] Piatnytska, H. T., Sinitsina, O. V. (2011). Vplyv vystavkovoi diialnosti na sotsialno-ekonomichnyi rozvytok rehionu [Impact of exhibition activity on the socio-economic development of the region]. Ekonomika i rehion [Economy and region]. no 3 (30), pp. 26-33.

[24] Robert, W., Rydell, John E. Finding and Kimberly D. Pelle (2000). Fair America: world's fairs in the United States [Fair America: world's fairs in the United States], The Hardcover edition from Smithsonian Books, 166 P.

[25] Suleimanova, K. A. (2009). Ekonomycheskyi effekt vystavochnoi deiatelnosty [Economic effect of exhibition activity]. Transportnoe delo Rossyy. no 12, pp. 96-99.

[26] Siurko, L. E. (2011). Otsinka efektyvnosti vystavkovoi diialnosti [Evaluation of the effectiveness of exhibition activities] Visnyk sotsialno-ekonomichnykh doslidzhen [Bulletin of socio-economic research], no 2 (42), pp. 343-347.

27. Tkachenko, T.I., Dupliak, T. P. (2016) Vystavkovyi biznes [Exhibition Business]: monohrafiia. KNTEU, 244 P.

[28] Farberov, V. I. (2002). Formuvannia efektyvnoho mekhanizmu upravlinnia vystavkovymy pidpryiemstvamy [Formation of effective mechanism for managing exhibition enterprises] : : avtoref. dys., Donetsk. Instytut ekonomiky promyslovosti NAN Ukrainy, 23 P.

[29] Fatkhutdynov, R. A. (1998). Stratehycheskyi menedzhment : Uchebnyk dlia vuzov. 2-e yzd., dop. Yntel-Syntez,. 416. P.

[30] Frolov, A. A. (2006). Sovershenstvovanye otsenky effektyvnosty Mezhdunarodnoi vystavochnoi deiatelnosty [Improving the evaluation of the effectiveness of international exhibition activities] avtoref. dys. HOU VPO Uralskyi hos. tekhn. unyversytet-UPY, $24 \mathrm{P}$.

[31] Sharkov, F. I. (2006) Vystavochnyj kommunikaczionnyj menedzhment (upravlenie vystavochnymi kommunikacziyami) [Exhibition Communication Management (Exhibition Communications Management)]. Alfa-Press, 256 P.

[32] Sheremet A.D. Metodyka fynansovoho analyza [The method of financial analysis]. Ynfra - M, 1995, 176 P.

[33] DSTU ISO 9000-2001. Systemy upravlinnia yakistiu. Osnovni polozhennia i slovnyk. Retrieved from: https://dnaop.com/ $\mathrm{html} / 41056 \_3 . \mathrm{html}$

[34] Yu. P. Surmin, V. D. Bakumenko, A. M. Mykhnenko (2010) Entsyklopedychnyi slovnyk z derzhavnoho upravlinnia [Encyclopedic Dictionary of Public Administration]. NADU, 820 P.

\section{СПИСОК ВИКОРИСТАНОЇ ЛІТЕРАТУРИ}

[1] Александрова, Н. В., Филоненко, И. К., (2006) Выставочный менеджмент: стратегия управления и маркетинговые коммуникации. Москва. Кн. изд-во. 384 с.

[2] Artz, R. (2007) Wettbewerbsfähigkeit europäischer Messeveranstalter: Entwicklung und empirische Anwendung eines multidimensionalen Bezugsrahmens. Kulner Wissenschaftsvl., 408 p.

[3] Бижанова, Е. М. (2006) Методы повышения эффективности выставочной деятельности предприятия. автореф. дис. на соискание науч. степени канд. эконом. наук : 08.00.05. Пенза. Пензенский гос. ун-т. 22 с.

[4] Вдовічена, О. Г. (2012) Виставково-ярмаркова діяльність як фактор соціально-економічного зростання регіону : дис. ... канд. екон. Наук : 08.00.05. ДВНЗ Ужгород. нац. ун-т. 236 с.

[5] Гагарин, Б. В., Ильин, Ю. Д. (2008) Методический поход к оценке эффективности выставки инновационной направленности. Инновации. № 3 (113). С. 116-120.

[6] Гуменна, О. В. (2005) Виставкова діяльність в АПК : автореф. дис. на наук. ступ канд. економ. наук : 08.02.02. Київ. ННЦ ІАЕ УААН. $22 \mathrm{c}$.

[7] Гусев, Е. Б., Прокудин, А. Г., Салащенко В. А. (2005) Выставочная деятельность в России и за рубежом. Москва. Кн. изд-во. 516 с.

[8] Добробабенко, Е. В., Добробабенко, Н. С., (2007) Выставка под «ключ». Готовые маркетинговые решения (+CD). Санкт-Петербург : Кн. изд-во. С.78-88.

[9] Долан Э. Дж., Линдсей Д. (1992) Рынок: микроэкономическая модель. Санкт-Петербург : Кн. изд-во. 496 с.

[10] Друкер, П. Ф. (1994) Эффективный управляющий. Москва : Кн. изд-во. 268 с.

[11] John E. Findling; Kimberly D. Pelle (2015) Encyclopedia of World's Fairs and Expositions by John E. Findling, McFarland \& Company. $474 \mathrm{P}$.

[12] Jennings, Hannah. (2002) Go to the flow: The exhibition design process made visible. Exhibitionist, no. 12 (1) pp. 34-36.

[13] Kádár, B. (2011) World Exhibitions as laboratories for structural innovation. Periodica polytechnica, no. 42/1, pp. 23-31.

[14] Касич, А. О., Назарова, М. В., Климович, Т. А. (2008) Інноваційна продукція як основа підвищення конкурентоспроможності підприємств України. Держава та регіони. № 2. С. 66-69. 


\section{ЕКОНОМІКА ТА МЕНЕДЖМЕНТ №2 2019}

[15] Кирилко, Н. М. (2015) Управління прийняттям рішення щодо участі у виставкових заходах підприємств легкої промисловості на базі застосування методу “decision tree”. Інноваційна економіка. № 5 [50] C. 144-152.

[16] Критсотакис, Л. Г. (1997) Торговые выставки и ярмарки. Техника участия и коммуникации. Москва : Кн. изд-во. 224 с.

[17] Лукашова, Л. В. (2009) Організація виставкової діяльності : [навч. посіб. для студ. вищих навч. закл.]. Київ. Кн. видBо. $272 \mathrm{c}$.

[18] Marc J. Epstein, Adriana Rejc Buhovac (2006). The Reporting of Organizational Risks for Internal and External DecisionMaking. Society of Management Accountants of Canada (CMA-Canada). 46 P.

[19] Мескон Майкл, Майкл Альберт, Франклин Хедоури (2019) Основы менеджмента. Москва : Кн. изд-во. 672 с.

[20] Стровский, Л. Е., Фролова, Е. Д., Стровский, Д. Л. (2012) Основы выставочно-ярмарочной деятельности. Москва : Кн. изд-во. 288 с.

[21] Пекар, В. О. (2009) Основи виставкової діяльності. Київ : Кн. вид-во. 166 с.

[22] Петелин, В. Г. (2005) Основы менеджмента выставочной деятельности. Москва : Кн. изд-во. 400 с.

[23] П'ятницька, Г. Т. (2011) Вплив виставкової діяльності на соціально-економічний розвиток регіону. Економіка і регіон. № 3 (30). C. 26-33.

[24] Robert W., Rydell, John E. Finding and Kimberly D. Pelle (2000) Fair America: world's fairs in the United States, Smithsonian Books. 166 P.

[25] Сулейманова, К. А. (2009) Экономический эффект выставочной деятельности. Транспортное дело России. № 12. C. 96-99.

[26] Сюрко, Л. Е. (2011) Оцінка ефективності виставкової діяльності. Вісник сочіально-економічних досліджень. № 2 (42). C. 343-347.

[27] Ткаченко, Т. І., Дупляк Т. П. (2016) Виставковий бізнес : монографія. Київ : Кн. вид-во. 244 с.

[28] Фарберов, В. І. (2002) Формування ефективного механізму управління виставковими підприємствами : автореф. дис. на здоб. наук. ступ. канд. екон. наук: 08.06.01. Донецьк. Інститут економіки промисловості НАН України. 23 с.

[29] Фатхутдинов, Р. А. (1998) Стратегический менеджмент. Москва. Кн. изд-во. 416 с.

[30] Фролов, А. А. (2006) Совершенствование оценки эффективности Международной выставочной деятельности : автореф. дис. на соиск. уч. степ. канд. эконом. наук 08.00.14. ГОУ ВПО «Уральский гос. техн. университет -УПИ». 24 с.

[31] Шарков, Ф. И. (2006) Выставочный коммуникационный менеджмент (управление выставочными коммуникациями). Москва. Кн. изд-во. 256 с.

[32] Шеремет, А. Д., Сайфулин, Р. С. (1995) Методика финансового анализа. Москва : Инфра. 176 с.

[33] ДСТУ ISO 9000-2001. Системи управління якістю. Основні положення і словник. URL: https://dnaop.com/ html/41056_3.html.

[34] Ковбасюк Ю. В., Трощинський, В. П., Сурмін, Ю. П., Бакуменко, В. Д., Михненко, А. М. (2010) Енциклопедичний словник 3 державного управління. Київ. Кн. вид-во. 820 с. 